\title{
How can tax compliance be incentivized? An experimental examination of voice and empathy
}

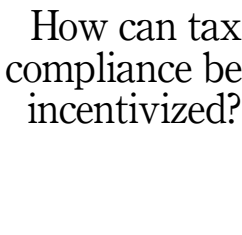

Mariam AbdelNabi

Economics Department, University of Warwick, Coventry, UK

Khedr Wanas

Independent Researcher, Cairo, Egypt, and

Sarah Mansour

Economics Department, Cairo University, Giza, Egypt

\begin{abstract}
Purpose - Tax evasion is an economic crime that nearly all world countries suffer from. Its consequences are countless, including poor public spending on infrastructure projects and social welfare programs, low economic growth and development, institutional mistrust and fiscal deficits. For developing countries in particular, targeting development programs and infrastructural investments requires an efficient tax collection policy to generate sufficient funds for such purposes. This makes the tax evasion problem a critical one and countering it extremely policy relevant. Based on evidence that shows how the understanding of taxpayers' behavior is an essential factor in fighting evasion, this paper aims to test different factors that might incentivize citizens using a behavioral and experimental approach, in non-Western educated industrialized rich democracies (nonWEIRD) countries, to comply more.

Design/methodology/approach - This paper uses a survey experiment to examine the impact of different behavioral primes on tax compliance behavior. Specifically, it observes subjects' compliance behavior in two contexts: voice and empathy. A total of 273 students from a big public university in Egypt were randomly selected to participate in this study.

Findings - In the "Voice" treatment, the explanatory variable (VOICE) was found statistically significant, thus confirming the hypothesis that democracy, through having a voice in the decision-making process, affects compliance positively. As for the "Empathy" treatment, the explanatory variable (EMPATHY) was also found significant. This confirms the second hypothesis that triggering feelings of empathy, through highlighting the good cause behind public spending that uses taxpayers' money, affects compliance behavior positively.

Research limitations/implications - Despite the fact that the experimental methodology is a methodology with high internal validity, examining the impact of a specific intervention on behavior, a replication of the experiment in other contexts might be useful in increasing the external validity of the findings. Specifically, conducting this experiment on a nonstudent sample might lead to even more powerful results by increasing the ecological validity of the results.

Practical implications - This study advocates a more behaviorally informed public policy. Specifically, Egyptian policymakers are recommended to adopt behavioral nudges as a complement to existing policies. The authors believe the findings, if confirmed by repeated experiments (lab, lab-in-the-field and rational choice theories on both student and non-student samples) in a number of Arab countries, might also help in offering cost-effective nudges for the Arab world policymakers, where culture and the political context are to a great extent similar.
\end{abstract}

(C) Mariam AbdelNabi, Khedr Wanas and Sarah Mansour. Published in Review of Economics and Political Science. Published by Emerald Publishing Limited. This article is published under the Creative Commons Attribution (CC BY 4.0) licence. Anyone may reproduce, distribute, translate and create derivative works of this article (for both commercial and non-commercial purposes), subject to full attribution to the original publication and authors. The full terms of this licence may be seen at http:// creativecommons.org/licences/by/4.0/legalcode

The authors acknowledge the support of the administration at Cairo University for providing the relevant information used in the "Empathy" treatment to avoid any deception to the students. The authors also confirm having no relevant or material financial interests that relate to the research described in this paper.

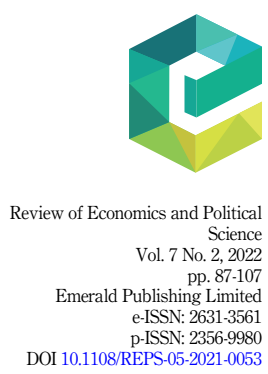


REPS

7,2

88

Social implications - The findings of the study have a number of social implications. Higher tax compliance will enable higher levels of public spending on a number of social targets such as education, health and welfare programs.

Originality/value - While the study builds on recent research examining how to incentivize tax compliance, it simultaneously seeks to make three contributions. First, the study design aims to apply recent advances in behavioral sciences (impact of voice and empathy) in a policy area that has not seen much use of such interventions in the Egyptian context (i.e. tax compliance). Second, the study is policy relevant in the sense that it aims to increase the effectiveness of existing government policies by complementing them with behavioral primes. Third, there is nearly no literature found applying this topic in a non-WEIRD country such as Egypt.

Keywords Empathy, Voice, Tax compliance, Survey experiment, Political institutions

Paper type Research paper

\section{Introduction}

Out of the many economic and social crimes that countries encounter, tax evasion remains a common major issue that is usually understated by authorities. Tax evasion is the act of not paying or underreporting taxes that are owed by citizens. The moment it was considered a crime, lawmakers started advocating severe punishments to those who commit it, ranging from imprisonment to monetary fines, or a combination of both, which never solved the problem. The problem lies in that the less money the government collects, the less public services it provides, undermining its legitimacy and causing social injustice, mistrust in its institutions and high budget deficits (Fjeldstad, 1996; Di Nola et al., 2021; Saidu and Dauda, 2014). Governments, especially those facing economic and social disturbances, thus need to readjust their policies to avoid further evasion that could undermine their development and growth prospects (Russo, 2010).

According to the International Monetary Fund (IMF), tax evasion results in the loss of 2$3 \%$ of $\mathrm{OECD}[1]$ countries' tax revenues every year, and around $6-13 \%$ of those of lowerincome countries (Norris et al., 2019). In the USA in 2019, tax evasion represented nearly threequarters of the country's fiscal deficit (Gale and Krupkin, 2019). This considerable amount of tax evasion in developed countries raises concerns about developing ones. In developing countries, measurements of tax evasion are difficult to compute, given the large base of informal economy, corrupt officials and the high costs of auditing. Consequently, most of the developing countries' budgets face what is known as a tax gap - a shortage in government revenues that is caused by collecting taxes less than the amount due. Low enforcement of policies and the lack of statistical and behavioral measures make it even harder to track reasons behind tax evasion, leading to wider deficits without proposed solutions. This paper focuses on Egypt, being the biggest Arab country in terms of population and one with dire need for funds to finance its sustainable development goals.

\subsection{Background}

For fiscal sustainability considerations, governments of developing countries usually opt for loans from international organizations like the IMF. These loans however come with conditionality where the governments of the borrowing countries have to adopt strict fiscal measures that call for the reduction of the government's expenditures and the increase of its tax rates. Egypt is not an exception in this. For example, during its 2016 IMF loan, Egypt's income tax rate was increased to reach $25 \%$, VAT was introduced and a simplified tax regime was applied. Yet, the country collected only $40 \%$ of the due taxes. In 2017, Egypt signed its first International Multilateral Anti-Tax Agreement to stick to an international commitment of combating evasion. In 2019, the Egyptian government embarked on reforming its tax collection policy [2]. This has effectively contributed to the reduction in the budget deficit from $9.5 \%$ of GDP in 2018/19 to approximately 7.2\% in 2019/20 (KPMG, 2020). Despite this, tax revenues in Egypt remain significantly lower than the MENA average (an estimate of $14 \%$ of Egypt's GDP, compared to around $28 \%$ of the GDP in the MENA region). 
Egypt is definitely not the only country facing tax evasion, despite its relentless efforts in combating them. The problem however is that these efforts are all conventional. They all rely on improving the "tax collection" aspect and not the "taxpayers" aspect. These regulations and conventional methods are costly and have proven not to be effective in increasing tax compliance. Taxpayers need to be incentivized to comply. Research, in behavioral economics, has concluded that understanding taxpayers' behavior is an essential factor in fighting evasion. This paper thus applies behavioral and experimental approaches to the tax evasion problem in Egypt in order to understand the taxpayer behavior and the factors that might incentivize higher compliance.

\subsection{Behavioral primes: motivation}

With the sustainable development strategy of 2030, Egypt's agenda and budget are being redirected toward more developmental programs and infrastructural investments. However, proceeding with these strategies without sufficient internal revenues has caused, and will continue to cause, Egypt to fall into a fiscal deficit and a high public debt. This shortage of revenues could be attributed, among other things, to inefficient tax collection policies and failure to tackle factors affecting taxpayers' behavior. Accordingly, researching into ways that could reduce the tax gap will have significant policy implications by strengthening the capacity of the Egyptian government specifically, and governments of developing countries in general, to achieve their goals for sustainable development.

This paper thus aims at testing, through a survey experiment, two factors that might incentivize Egyptians to comply more with taxes - (1) having a voice in the decision-making process and (2) triggering empathy on the use of taxpayers' money by highlighting the social benefit of public spending.

The reasons behind our choice of these two behavioral primes are twofold. First, the 2011 Arab uprisings have caused a significant shift in Arabs' attitudes toward a more democratic governing system. In fact, Arabs' perceptions of democracy being the best governing system has been increasing, with statistics reporting that more than two-thirds of Arabs believe that political participation is more likely to rise under a democratic system. Moreover, 54\% of Egyptians associate potential economic and social problems to a nondemocratic government (Arab Barometer, 2018). Second, according to Hofstede index [3], Egypt scores 25 in individualism, which is a relatively low score, reflecting that Egypt is a collectivist society where Egyptians tend to feel for those around them and to put the notion of togetherness on top of their concerns.

The rest of the paper is divided as follows. Section 2 reviews the literature on both conventional and unconventional methods for fighting tax evasion. Section 3 presents the theoretical framework and derives the hypotheses of the study. Section 4 covers the methodology. Section 5 discusses the results. Finally, Section 6 provides the conclusion.

\section{Literature review}

This section reviews the literature on the use of both conventional and unconventional methods for fighting tax evasion. Starting with the conventional taxation theories, various economic theories have been proposed, trying to reach the optimal policy that would run an effective tax system with the lowest possible tax evasion rate. Becker (1968) used the expected utility theory to formulate the first economic crime model that nearly all tax evasion theories that followed were based on. Becker developed the rational choice theory (RCT) that, for several decades, had a role in explaining criminal behavior and setting punishments for it. According to Becker, people make decisions based on cost-benefit analyses. Criminals, or tax evaders in our case, conduct cost-benefit analyses to measure the expected utility they might gain from tax evasion. In other words, the RCT treats crime as a rational choice. The crime model is as follows:

$$
(1-p) u_{s}+p u_{f}>U
$$


REPS

7,2

90

where $p$ represents the probability of punishment, $u_{s}$ represents the expected utility resulting from successfully evading taxes and $u_{f}$ represents the expected utility of getting caught and being punished. On the right-hand side, $U$ represents the expected utility when no crime is committed. An individual, according to the RCT, will only evade taxes if the left-hand side of this inequality (net gains of evading taxes) is greater than the right-hand side (net gains of paying taxes). The model implies that individuals will deter from tax evasion if the severity of the punishment or the chance of being detected are high.

In the same line, Allingham and Sandmo (1972) introduced the earliest general theory that explains the individual's decision to evade taxes based on Becker's crime model. The $A$-S model is quite simple. It assumes that an individual's decision to evade depends on maximizing their expected utility $(V)$, given their gross income $(W)$, the evaded amount $(E)$, their subjective probability of detection ( $($ ) , the tax rate paid on the gross income $(t)$ and the penalty tax rate paid on the evaded amount $(L)$, in case of detection. Taxpayers are expected to formulate two utility functions; one that includes $p$ and $L$, the case of detection, and one without them, the case of not getting caught. Assuming all taxpayers are risk-averse, they will choose $E$ based on their subjective $p$ that allows for the maximization of $V$, in both cases. After formulating their functions, taxpayers compare the utilities of both, and accordingly, make their evasion decision. Given the assumption that all taxpayers are risk-averse, an increase in either $p$ or $L$ is expected to reduce the level of tax evasion. If this model, however, was completely true, there would have been a very low number of evaders, which is not the general case (Sandmo, 2005).

The above mathematical models of economic decision-making have always relied on the core assumption of homo economicus; that individuals' rationality is limitless. It implies that economic agents have access to all market information, can easily foresee the consequences of their decisions and have the ability to calculate their optimal decisions, giving them the chance to always choose the option that maximizes their expected utility ( $\mathrm{Ng}$ and Tseng, 2008). Simon (1955) proposed a new theory that challenged the homo economicus assumption arguing that individuals' rationality is bounded by the information they have access to, their cognitive capacity and the available time to make decisions. Economists, as a result, added an error term in their economic models that accounts for the random error that individuals make when their decisions are not optimal.

It was only when Kahneman and Tversky (1972), Tversky and Kahneman (1974) incorporated psychology into economics that another theory came to challenge Simon's. They argued that the "random" errors, that cancel out on average in economic models, may not be random after all. They proposed that if errors can be predicted, then deviations from rational choice models can also be predicted. They did not build a new theory to overthrow the neoclassical economic models, rather they only suggested the incorporation of the human element in economic models for more accurate prediction.

Based on Kahneman and Tversky's contributions, Thaler and Sunstein (2008) introduced the notion of the "Nudge"; a cheap, easy-to-avoid intervention that works around the predictable errors or biases, that individuals fall into, in order to promote better decisionmaking, "without forbidding any options or significantly changing [individuals'] economic incentives". In other words, a policy that punishes tax evaders may not be as effective as telling evaders that their neighbors pay their taxes, unlike them, in hopes of encouraging more compliance through triggering self-shame. Thaler and Sunstein argued that if governmental units and officials altered their policies in ways that nudged people toward better decisions, rather than imposing the conventional command and control regulations, results could be in favor of individual, social and economic welfare (Kosters and der Heijden, 2015). Through experimenting and understanding the heuristics, biases and predictable errors that trigger people's cognitive systems, more than 150 governments around the world created different applications of the concept of nudging that helped improve decision-making (OECD, 2017). 
Priming is a nudging technique that subtly puts subjects in contexts where they are prompted to act, think about or recollect specific information that may influence a decision they are asked to make in a subsequent, unrelated task, without them necessarily being aware of such influence. These contexts can be reading notes, watching videos, listening to music or any other method that triggers the cognitive constructs and behavior of participants (Cohn and Maréchal, 2016). The idea behind priming is that it stimulates the availability heuristic. According to Tversky and Kahneman (1973), the availability heuristic is when individuals tend to rely on immediate information, that is at the top of their minds, when evaluating their decisions. Priming, in this case, allows specific information to be the most available in the minds of individuals in order to use it when making their decisions. Generally, there are two priming theories. The traditional theory suggests that priming participants to behave in a certain way can only automatically activate thoughts related to processes required to behave in that way. The modern theory of priming, however, suggests that activating a participant's cognitive construct is not the sole influence on their decision. Unlike traditional priming, mindset priming suggests that participants have more control over what influences them. They usually consider the provoked thought, along with their values, norms, goals and other situational factors before making their decision (Fujita and Trope, 2014).

\section{Theoretical framework and derivation of hypotheses}

This section presents the theoretical underpinnings of the two behavioral primes that this paper seeks to examine: Voice and Empathy and their impact on tax compliance behavior. It starts with reviewing the literature and theories on the impact of having a voice on tax compliance behavior, and how this leads to the derivation of the first hypothesis of the paper. It then moves to those on empathy and compliance, and accordingly how this derives the second hypothesis of the paper.

\subsection{Voice and tax compliance}

It has been shown that when political and economic institutions delegate part of the decisionmaking process of a certain policy to their citizens, there is a higher chance of compliance with said policy. This is why, for instance, democratic policy-making, or one that takes into account citizens' opinions, has proven to be more effective than an autocratic one (Deacon, 2009; Persson and Tabellini, 2005; Abdullah and Abdul Rahman, 2015). Evidence from behavioral science also confirmed that participation in the allocation and decision-making process has a positive impact on compliance due to the legitimacy it lends to the system and the need to show signs of honesty, a norm that is triggered by inclusion (McEwen and Maiman, 1986). It was also shown that people tend to behave in a way that is consistent with their promises (Cialdini et al., 1999). This notion of commitment consistency implies that people will be more willing to comply if they committed themselves to certain positions, something that materializes when an individual is part of the decision process [4].

With regard to tax compliance, it was proven that compliance gets affected by the method expenditure decisions are made. Taxpayers are inclined to comply less if they feel they have little say or no voice in the way their taxes are spent (Alm et al., 1992; Pommerehne and WeckHanneman, 1996). Torgler (2005), for instance, tested the effect of democracy on tax compliance and found that citizens are more motivated to comply with their taxes when their government takes their opinions on how to spend these taxes into consideration.

Olken (2010) conducted a field experiment on 48 Indonesian villages where he proposed developmental projects and then randomly assigned each village to one of two treatments. The first treatment was to gather elites of the selected villages to attend meetings discussing the proposals and then choosing one. The second treatment was more of a participatory process where, based on a direct election plebiscite, villagers voted on their projects. Data showed that the latter treatment allowed for more participation from the villagers, which resulted in higher 
REPS

7,2

\section{2}

satisfaction and more legitimacy. Therefore, when villagers had a say in choosing the project, the willingness to contribute was higher. Dal Bo (2010) had 276 subjects from Brown University playing the prisoner's dilemma game under different settings. The aim was to test whether subjects under exogenous game modifications will contribute more or less than those under endogenous, or voted for, game modifications. Results proved that endogenous participation, or inclusion, allowed for more contributions in the following rounds of the game.

Another study tested a similar hypothesis but added to it the spillover effect of democracy. Kamei (2016) randomly selected 300 undergraduates from Brown University to play a public goods game [5]. Groups in the game consisted of two participants, and the game consisted of two phases. The first phase was a typical public goods game, where subjects were either in a "democratic setup" or in an "undemocratic setup." After Phase 1, subjects were randomly assigned to a perfect stranger, and the game, with the same setup, was repeated. Results of descriptive statistics and regression analyses showed that not only did participants contribute more in "democratic setups" in Phase 1 but also those exposed to the "democratic setup" in Phase 1 contributed much more in Phase 2 than those who were under the "undemocratic setup." Kamei concluded that democracy prompts pro-social behavior and has a spillover effect in later situations.

Based on the above, our first hypothesis reads as follows:

H1. Compliance will be higher when individuals are given a voice in the decision-making process than when the use of collected money is being imposed on them.

\subsection{Empathy and tax compliance}

A lot of literature has been devoted to studying how an individual's perception of the fairness of the exchange in a transaction affects his or her compliance in that transaction (on how this applies to tax compliance see Cowell, 1992; Alm et al., 1993; Hassan et al., 2021). Specifically, tax compliance is affected by the nature of government expenditures with compliance being lower in periods where taxpayers do not approve the type of expenditure their government is funding through their money (Cowell et al., 1988). For instance, in the USA, tax revenues were negatively affected at the time of the Vietnam war. Moreover, in governments that are unpopular or distrusted, tax compliance is usually used by the citizens to convey a message of dissatisfaction (Mansour et al., 2021).

Some studies have looked at this relationship from a psychological and cognitive angle. Lamberton et al. (2014) attributed tax evasion to a psychological characteristic of the tax process; the decoupling of tax payments and the public goods obtained in return. As perceptions about these benefits are normally lower at the time of payment, this decoupling leads to lower tax compliance (Thaler, 1999). As a way of solving this problem, policymakers have started publicizing information on the allocation of tax revenues across different expenditure categories in order to better inform taxpayers about where their money will be spent (White House, 2011).

Provision of information on the uses and benefits of taxation thus increases tax compliance (Sussman and Olivola, 2011; Djawadi and Fahr, 2013). There is not much literature however on how feelings of empathy, triggered by the information provided on how taxpayers' money is spent on the less privileged, could be driving these higher compliance rates. The use of empathy-triggering information to increase compliance is a line of research that aligns with the literature on generosity and how it can be increased by providing information on the beneficiary (Bohnet and Frey, 1999). Moreover, people in general get a psychological boost when they perform good deeds, when they help each other or when they contribute to the general well-being of others (Steger et al., 2008).

Based on the above, our paper argues that triggering taxpayers' feelings of empathy, by providing them with information on the good cause behind public spending and the fact that taxpayers' money will be used to help the less fortunate segments of the population, increases tax compliance. 
On the relation between emotions and tax compliance, many experiments have been conducted, such as stigma of noncompliance (Cowell, 1990; Cummings et al., 2006), perceptions of others' compliance (Alm and McKee, 2004; Wenzel, 2005) and concern about others' welfare (Bosco and Mittone, 1997). However, the literature is quite short on the specific relation between empathy and tax compliance. There are, nonetheless, some studies that tested a more general relation - the relation between empathy and monetary contributions. In a public goods experiment, Czap and Bonakdarian (2010) tested how participants' contributions vary based on three psychological traits: empathy, locus of control and trust. The empathy hypothesis was that the more empathetic a person is, the more willing they are to invest in a group project. The results showed that participants who considered themselves empathetic contributed more money to the project.

Batson et al. (2002) conducted an experiment at the University of Kansas with 54 psychology students assigned to three different experimental groups, where they all listened to the same interview about a convicted fictional user and seller of heroin. Those in the empathy treatment were told that this person was real. Not only did this group's attitude change toward people addicted to hard drugs, but they also suggested that funds from their Student Senate should be donated to an agency that helps drug addicts - even when participants were not asked to do so. This shows that externally induced empathy can trigger some positive attitudes toward stigmatized groups.

Alm and Calvet (2013) conducted a series of laboratory one-shot tax compliance games in order to measure the impact of both identifying sympathy and promoting empathy on tax compliance. In order to promote empathy, researchers primed subjects by making them read and write, in their own words, some moral values. Their results showed that a participant's exposure to moral instructions reduces their willingness to behave negatively. More specifically, when participants are exposed to empathy primes, they become less inclined to evade taxes, increasing evidence that empathy influences tax compliance decisions.

Although there are only a few studies testing the exact relation between empathy and tax compliance behavior, the above literature proves that empathy, whether intrinsic or externally induced, influences decision-making, especially monetary decisions. People's morals and relations to others do affect how they behave, making them more willing to change their attitudes or actions in order to help others. This evidence supports our second hypothesis for this study that empathy can result in more tax compliance. Our intervention is however different from previous studies. It triggers empathy through giving subjects information on how collected money will be spent on a good cause; paying tuition fees for those students who lie below the poverty line. Our second hypothesis thus reads as follows:

H2. Triggering individuals' feelings of empathy, by providing them with information that taxpayers' money will be spent on the less-privileged, will incentivize them to comply more.

\section{Methodology}

This paper aims at examining the impact of two behavioral interventions, Voice and Empathy, on tax compliance behavior, using a survey experiment [6]. This section provides all methodological details.

\subsection{Participants}

Two-hundred-seventy-three students, from a big public university in Egypt, participated in the study: 197 females and 76 males [7]. The survey experiment was conducted online, in December 2019 over a period of two weeks [8]. Participants were randomly assigned one of three conditions: Treatment 1 , Treatment 2 or a control. 
REPS

7,2

94

There are several reasons why our student sample could be relevant in drawing conclusion on tax compliance behavior. First, university students will soon join the job market, meaning that in a couple of years, they will be subject to a tax bracket, so we believe it is crucial to understand what factors might affect the behavior of Egypt's future taxpayers. Second, in most experimental studies, abstracting the effect of the nudge on behavior implies that the student sample responses may be as accurate as the responses of real taxpayers.

\subsection{Survey experiment design}

We designed three experimental surveys [9] that were distributed equally over our sample of 273 participants. Each survey received 91 responses, and all were considered in our analysis [10]. These surveys were divided into two treatments and a control, where the treatments tested the effect of our two behavioral interventions: Voice and Empathy. Survey questions were tailored to fit our sample of university students. The exact wording of the questions is presented in Appendix 2.

Environment of the experiment. We created an environment that fits our university student sample as follows. (1) "Tuition fees", being compulsory payments, represented due taxes and (2) "an increase in the tuition fees that was not added, by mistake, on the student's tuition bill" represented that segment of the tax that could be evaded. Subjects were thus put in the context of a very easy opportunity to free ride, and hence, their willingness to change their status quo in order to comply was tested with and without our primes.

Survey questions and controls. Three blocs of questions were asked. The first bloc consisted of five demographic questions to collect data on the characteristics of our sample. The second bloc of questions measures our control variables and potential mechanisms; honesty, empathy and religiosity. We controlled for honesty and empathy because we were concerned that subjects might comply with taxes just because they are honest or empathetic individuals and not because they were influenced by the prime. As for religiosity, given that $91.1 \%$ of Egyptians are Muslims, according to the World Factbook, we assumed that religious individuals might be affected by the fact that tax evasion is considered by both the Quran and the Sunnah not only illegal and unethical but also a mortal sin (A.R, 2012). This raised the concern that some individuals might choose to comply just because Islam forbids not to, and not due to the prime. Therefore, to avoid misinterpreting the effect of our primes on tax compliance, we controlled for these three variables that we believe might have an effect on tax compliance.

The last bloc in our surveys proxies for the willingness to comply with taxes. Specifically, participants were introduced to a scenario where tuition fees are increased by $5 \%$, but this increase was not added to their bill by mistake. They were then asked whether they will report the mistake and pay the higher fees or not [11]. For the control group, the question is asked without any primes. For Treatments 1 and 2, however, a prime is introduced prior to this question [12]. Specifically, in the Voice treatment, participants were primed as having a role in the University's decision-making process, and this role involves having a say on how to spend the funds raised from the higher tuition fees [13]. This proxies taxpayer agency (Lamberton et al., 2014). In the Empathy treatment, subjects were informed about the number of colleagues at Cairo University who are below the poverty line and on whom the extra funds generated from the increase in tuition fees will be spent [14]. This intervention proxies the recoupling of tax payments and tax benefits mentioned above (Lamberton et al., 2014) and specially benefits that highlight a good cause. As mentioned above, both primes are hypothesized to result in higher compliance rates.

\section{Results and discussion}

We first start with a discussion of our sample characteristics. According to Table 1, females represented most of our overall sample (around $72 \%$ ). The majority of subjects belonged to 


\begin{tabular}{|c|c|c|c|}
\hline & Frequency & Percentage $(\%)$ & How can tax \\
\hline $\begin{array}{l}\text { Gender } \\
\text { Female }\end{array}$ & 197 & 72.16 & incentivized? \\
\hline $\begin{array}{l}\text { Age } \\
15-24\end{array}$ & 252 & 92.31 & \\
\hline $\begin{array}{l}\text { Education level } \\
\text { Bachelor's degree } \\
\text { Master's degree }\end{array}$ & $\begin{array}{r}223 \\
22\end{array}$ & $\begin{array}{r}81.68 \\
8.06\end{array}$ & 95 \\
\hline $\begin{array}{l}\text { Income level } \\
\text { Less than } 10,000 \\
10,000-14,999 \\
15,000-19,999 \\
20,000-24,999 \\
25,000-30,000 \\
\text { More than } 30,000\end{array}$ & $\begin{array}{l}39 \\
56 \\
48 \\
43 \\
25 \\
62\end{array}$ & $\begin{array}{r}14.29 \\
20.51 \\
17.58 \\
15.75 \\
9.16 \\
22.71\end{array}$ & \\
\hline $\begin{array}{l}\text { Tuition fees } \\
\text { Less than } 2,000 \\
2,000-4,999 \\
5,000-7,999 \\
8,000-10,999 \\
11,000-15,000 \\
\text { More than } 15,000\end{array}$ & $\begin{array}{r}35 \\
9 \\
9 \\
17 \\
54 \\
149\end{array}$ & $\begin{array}{c}13 \\
3 \\
3 \\
6 \\
19.78 \\
54.58\end{array}$ & $\begin{array}{r}\text { Table 1. } \\
\text { Sample descriptive } \\
\text { statistics }\end{array}$ \\
\hline
\end{tabular}

the first age bracket " $15-24$ " confirming the nature of our sample being university students. Income levels varied considerably, reflecting all income groups.

We then move to showing the pure effect of our primes on compliance behavior, with no controls included. Figure 1 demonstrates the frequency of compliance across all groups.

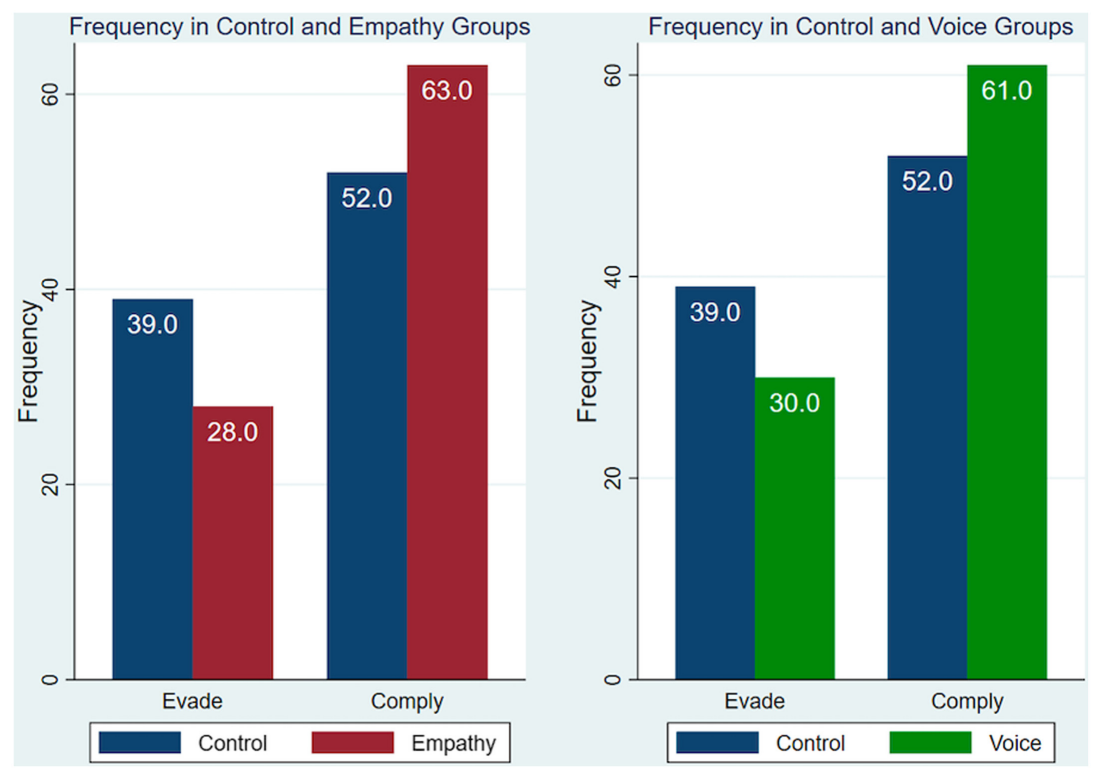

Figure 1. Frequency of compliance across groups 
REPS

7,2

96

We notice that subjects in the control group were the least likely to comply; only 52 of 91 did comply. However, subjects in the Empathy treatment were the most likely to comply, slightly higher than subjects in the Voice treatment; with only two extra compliances. Chi-Square tests were conducted in order to have a more accurate measure of the statistical significance of our findings. Based on these tests, we can conclude that the comparison between the Empathy treatment and the control is significant $(p<0.1)$ [15]. This means that, on average, Empathy results in a higher willingness to comply and a lower willingness to evade compared to those in the control who did not get this empathy-triggering information. As for the Voice prime, the test does not show significant difference [16].

To sum up what is depicted in Figure 1, the majority of our sample complied, around $64.5 \%$. However, it is worth noting that higher compliance is observed in our two treatments than in the control, while higher evasion is observed in the control than in the two treatments. Overall, around $40 \%$ of those who evaded where in the control group. The Empathy treatment scored the highest compliance and lowest evasion, slightly above the Voice treatment. These mere observations are interesting to note; nonetheless, a further, deeper analysis is required to measure the significance of such differences. In what follows, the study will provide a deeper regression analysis and hypothesis testing for these observations in order to test significance of compliance in the two treatment groups and evasion in the control group.

Since most of the survey responses are categorical, we first needed to encode our data before plugging them into the regression model [17]. Our dependent variable measured the subject's willingness to comply. It took the value of 1 if the subject reported the problem of wrong tuition fees, and the value of 0 if the subject did not report the problem and chose to pay the wrong value of tuition fees without the increase. As for our main independent variables, voice and informed, they were coded as dummy variables as well. "Voice" took the value 1 if the treatment was the decision-making treatment and 0 for the control group. "Empathy" took the value 1 if the treatment was the Empathy treatment and 0 for the control group. Regarding our controls, honesty, emotional and religiosity, we created an index for each to capture the three questions referring to them in the survey and to avoid having too many variables in the regression [18]. The indices take values between 0 and 1 , such that the closer the value is to 1 , the more honest, more emotional and/or more religious the person is.

Two logistic regressions were then conducted; one that measures control group results against Voice treatment results, and the other measures control group results against Empathy treatment results.

\subsection{Model specification}

$$
\begin{aligned}
\text { Tax Compliance }= & \beta_{0}+\beta_{1} \text { Age }+\beta_{2} \text { Female }+\beta_{3} \text { Education }+\beta_{4} \text { Income }+\beta_{5} \text { Fees } \\
& \left.+\beta_{6} \text { Honesty }+\beta_{7} \text { Empathy }+\beta_{8} \text { Religiosity }+\beta_{9} \text { Voice (Information }\right)
\end{aligned}
$$

\subsection{Treatment 1: voice}

Table 2 shows the results of our logistic model [19]. Classification shows that the model's hits and classification accuracy is $68.7 \% ; 29 \%$ of the noncompliers were predicted by the model not to comply, and $92.9 \%$ of the compliers were predicted to comply. Regarding our main explanatory variable, Voice, we find that it is statistically significant. This implies that students, who hold responsibility and feel included and having a voice in the decision-making process, are significantly more likely to comply than those who do not. Regarding our controls, we find that a student's level of empathy is a main determinant of their willingness to comply: The more empathetic a student is, the more likely they are to comply. 


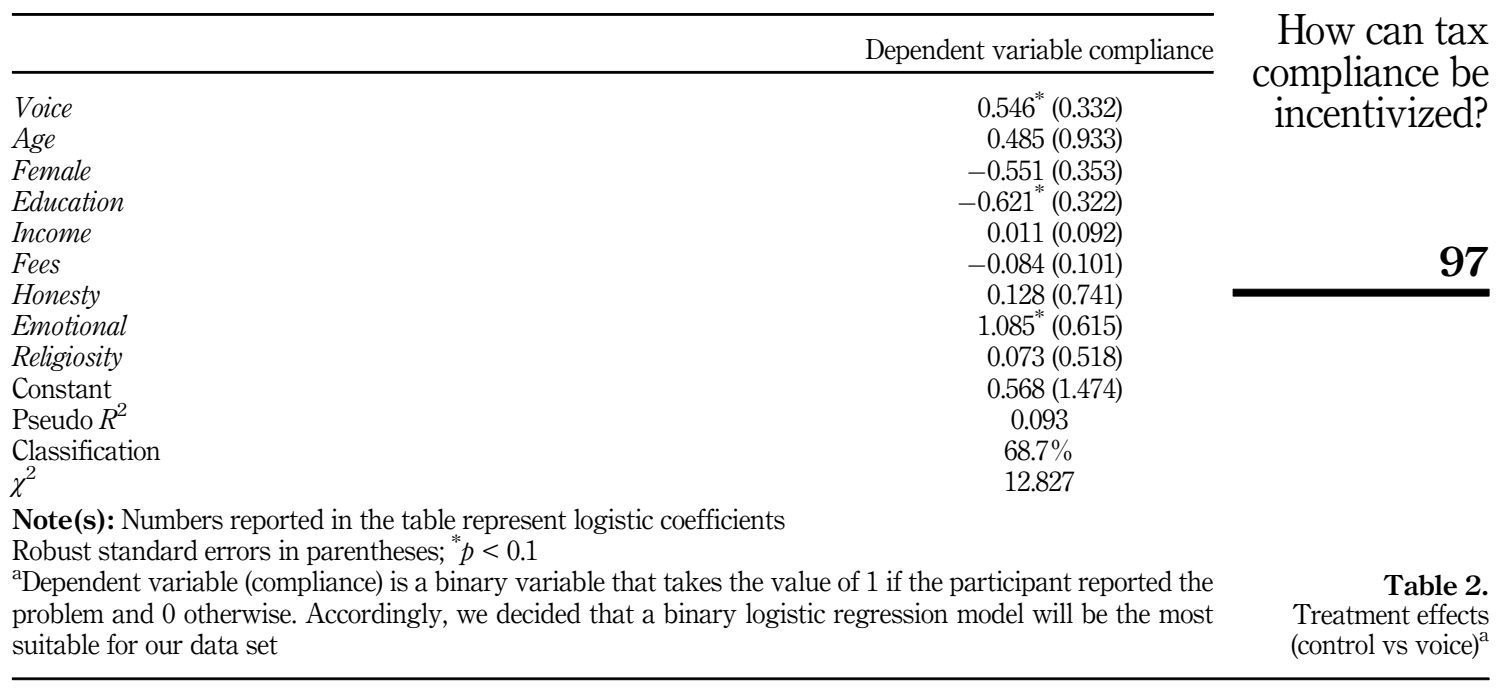

Based on these results, we therefore find enough evidence to accept our first hypothesis (H1) giving individuals a voice in the decision-making process incentivizes them to comply more.

\subsection{Treatment 2: empathy}

Table 3 shows the results of our logistic regression [20]. We find that our main independent variable, "Informed", is significant. This implies that students who were informed about how the collected money will be spent, and specifically the good cause behind the increase of tuition fees where it will be used to fund less-privileged colleagues, are significantly more likely to comply than those who were not given that piece of information. As for our controls, those subjects who are more empathetic are significantly more likely to comply more and females are less likely to comply than males.

We therefore, find enough evidence to accept our second hypothesis (H2) - Triggering individuals' feelings of empathy, by providing them with information that collected money will be spent on the less-privileged, will incentivize them to comply more.

\begin{tabular}{lc}
\hline & Dependent variable compliance \\
\hline Empathy & $0.586^{*}(0.330)$ \\
Female & $-0.860^{*}(0.355)$ \\
Education & $-0.381(0.317)$ \\
Income & $-0.059(0.094)$ \\
Honesty & $0.989(0.750)$ \\
Emotional & $0.801^{*}(0.432)$ \\
Religiosity & $0.335(0.511)$ \\
Constant & $0.457(0.511)$ \\
Pseudo $R$-squared & 0.103 \\
Classification & $66.5 \%$ \\
$\chi^{2}$ & 14.290 \\
Note(s): Numbers reported in the table represent logistic coefficients & \\
Robust standard errors in parentheses; $p<0.1$ & \\
\hline
\end{tabular}


REPS

7,2

98

\section{Conclusion}

Tax evasion is a major problem in almost all societies. Even in developed countries, with relatively low levels of tax noncompliance, the loss to revenue is huge. Not only does this threaten funds for provision of government goods and services, but it also contributes to social inequality, institutional mistrust, high budget deficits and low economic growth and development. This paper focuses on Egypt for two reasons. First, it is the biggest Arab country in terms of population. Second, it has embarked on a reform program for sustainable development that needs an efficient tax system to guarantee its success.

Initially, research on tax compliance was dominated by an economic analysis and a rational choice theory that frames the taxpayer's decision to comply or not as a rational attempt to maximize profits. More recent research, however, has proven that noneconomic social factors also influence taxpaying behavior; for instance, political institutions, ethics, perceptions of others' compliance and many others. In our paper, we investigated two behavioral primes that might incentivize Egyptians to comply more: (1) having a voice in the allocation of taxes and collected funds and (2) triggering empathy with public spending of taxpayers' money. The reasons behind the choice of these two behavioral interventions were twofold. First, following the Arab Spring in 2011, Egyptians started believing in democracy and the importance of having a voice in the decision-making process (WVS, different waves). Second, as per Hofstede index, Egypt is a collectivist country, meaning that its citizens are highly empathetic and care for those around them.

A survey experiment, with two treatments and a control, was conducted on 273 Egyptian university students to examine the abovementioned interventions. All three surveys provide participants with an easy opportunity to free ride and not pay an increase in their tuition fees; however, the Voice and Empathy treatments had primes inserted. While Voice prime puts participants in a context where their opinions are valued (taxpayer agency hypothesis), Empathy prime puts them in a context where they are informed that the collected money will be spent on those below the poverty line (empathy hypothesis). Our findings show that both primes have proven to be statistically significant in increasing an individual's willingness to comply - allowing us to accept both of our hypotheses. It is worth noting however that our study had a number of limitations. First, females represent the majority of our sample. This decreases, to some extent, the external validity of our findings as males represent the main breadwinner in most of the households in Egypt and hence are the ones most likely to be evading taxes. The fact that the majority of our sample is females does not show how males are going to behave under such primes. Second, the majority of students in our sample are paying high tuition fees. With the majority of Egyptian students going to public universities where tuition fees are almost zero, this decreases the representativeness of our sample.

Based on these findings, it is evident that considering the factors that affect the behavior of taxpayers and thus adopting behaviorally informed policies allows for a better policy formulation. Accordingly, the Egyptian government is recommended to complement its existing policies with nudges to increase the effectiveness of these policies. To achieve this, an initiative to coordinate with big public universities, where different interventions, like peer pressure, reputation and others, can be tested in the experimental labs of these universities and can be a good starting point where nudges get tested on an easy sample. A second step would be to conduct lab-in-the-field experiments on real taxpayers in order to increase the ecological validity of the results, which was a limitation of the current study which used a nontaxpayer student sample. A third step would be to conduct RCTs in order to increase the representativeness of the sample.

\section{Notes}

1. OECD stands for the Organization for Economic Cooperation and Development. 
2. This was a recent update, during May 2019, when Abdel Azim Hussein, the Head of the Tax Authority, drafted a change to the Income Tax Act in order to improve collection, without increasing tax rates. This included training the internal tax committees, improving the filing and procedures of collecting taxes, and including new tools that can decrease tax evasion. This update mainly targeted an increase in the tax revenue by $0.5 \%$.

3. Hofstede index is a commonly used measure to assess cultural differences between countries. It relies on six dimensions to explain the qualities and attributes of cultures on a scale from 0 to 100 . One of these dimensions is "Individualism," which addresses the "the degree of interdependence a society maintains among its members (Country Comparison - Hofstede Insights, 2019). In an individualist society, citizens prioritize themselves and their direct families, whereas in a collectivist one, citizens share a concern for the whole society.

4. On salience of pre-commitments, see Thaler and Benartzi (2004) and Rogers et al. (2014).

5. Note that a public good game is a game in experimental economics used to proxy tax payment behavior.

6. A survey experiment is an experiment that is embedded within a survey in order to test for the impact of a specific prime on behavior. The control group, in this experiment, is used as a benchmark to compare the effect of the different treatments.

7. Recruitment for the survey was done online by posting an announcement on a social media platform for student activities that is exclusive to Cairo University students.

8. An email that included the link to the survey was sent only to those students who voluntarily showed interest to take part in the study. Volunteers are students at different faculties at Cairo University. Filling the survey required 15 min of a participant's time.

9. See Appendix 2 for more details.

10. We have run a balanced one-way analysis of variance power calculation with the following parameters to get an initial estimate of the sample size (groups $=2$ : comparing between the control and one treatment at a time), alpha (significance level) $=0.05$, power $=0.8$, effect size $=0.2$ (which is a small effect following Jacob Cohen's recommendations (Schäfer and Schwarz, 2019). The calculation yielded a sample size of approximately 99 subjects for each group. Our sample size of 92 subjects per treatment/group was therefore close to the suggested sample size.

11. The exact wording of the questions is presented in Appendix 2.

12. For the exact wording of the primes, check Appendix 2.

13. Note that subjects in this treatment were neither given options to choose from nor were they allowed to say their preferences on how to spend these additional funds but were informed that their role allows them to have a say on this.

14. In the Voice treatment, participants are told to imagine that they are the head of their student union and that their opinion is highly valued by their college; hence feel responsible. In the Empathy treatment, on the other hand, they are told that the increase in tuition fees will fund the education of less-privileged students.

15. When comparing the distributions of compliance between Control and Empathy, the $\chi^{2}$ statistic $=2.858, \operatorname{Pr}=0.091$ and when comparing the proportion of noncompliance between Control and Empathy, the $z$ statistic $=1.326, \operatorname{Pr}=0.092$.

16. When comparing the distributions of compliance between Control and Voice, the $\chi^{2}$ statistic $=1.891, \operatorname{Pr}=0.169$ and when comparing the proportion of compliance between Control and Voice, the $z$ statistic $=-0.8435, \operatorname{Pr}=0.199$.

17. See Table A1 in Appendix 1 for summary of variables.

18. Each index gave equal weights to the 3 questions. For more details on the questions, check Appendix 2. 
REPS

7,2

19. In order to account for the several control variables that the model has, we constructed a nested logistic regression model that consists of nine blocks, where each block adds an extra independent variable to measure its confounding effect and significance. The reduced model only has the prime variable, while the full model has all variables (See the Appendix for details).

20. As with the previous treatment, we constructed a nested logistic regression model that consists of nine blocks, where each block adds an extra independent variable to measure its confounding effect and significance (see the Appendix).

21. All surveys ask the same questions, the only difference is Question 10.

\section{References}

Abdullah, N.N. and Abdul Rahman, M. (2015), "The use of deliberative democracy in public policy making process", Public Policy and Administration Research, Vol. 5 No. 3, pp. 221-229.

Allingham, M.G. and Sandmo, A. (1972), "Income tax evasion: a theoretical analysis", Journal of Public Economics, Vol. 1 Nos 3-4, pp. 323-338.

Alm, J. and Calvet, R.D. (2013), "Sympathy, empathy, and tax compliance", Journal of Economic Psychology.

Alm, J. and McKee, M. (2004), “Tax compliance as a coordination game”, Journal of Economic Behavior and Organization, Vol. 54, pp. 297-312.

Alm, J., McClelland, G.H. and Schulze, W.D. (1992), "Why do people pay taxes?", Journal of Public Economics, Vol. 48 No. 1, pp. 21-38.

Alm, J., Jackson, B. and McKee, M. (1993), "Fiscal exchange, collective decision institutions, and tax compliance", Journal of Economic Behavior and Organization, Vol. 22 No. 3, pp. 285-303.

Arab Barometer (2018), "Democracy in the Middle East and North Africa: five years after the Arab uprisings", Arab Barometer, Wave IV, pp. 3-9, available at: https://www.arabbarometer.org/wpcontent/uploads/Democracy_Public-Opinion_Middle-east_North-Africa_2018.pdf.

Batson, C.D., Chang, J., Orr, R. and Rowland, J. (2002), "Empathy, attitudes, and action: can feeling for a member of a stigmatized group motivate one to help the group?", Personality and Social Psychology Bulletin, Vol. 28 No. 12, pp. 1656-1666.

Becker, G.S. (1968), “Crime and punishment: an economic approach”, in The Economic Dimensions of Crime, Palgrave Macmillan, London, pp. 13-68.

Bohnet, I. and Frey, B. (1999), "Social distance and other-regarding behavior in dictator games: comment", The American Economic Review, Vol. 89 No. 1, pp. 335-339.

Bosco, L. and Mittone, L. (1997), "Tax evasion and moral constraints: some experimental evidence", Kyklos, Vol. 50 No. 3, pp. 297-324.

Cialdini, R., Wosinska, W., Barrett, D. and Butner, J. (1999), "Compliance with a request in two cultures: the differential influence of social proof and commitment/consistency on collectivists and individualists", Personality and Social Psychology Bulletin, Vol. 25 No. 10, pp. 1242-1253.

Cohn, A. and Maréchal, M.A. (2016), "Priming in economics", Current Opinion in Psychology, Vol. 12, pp. 17-21.

Country Comparison - Hofstede Insights (2019), available at: https:/www.hofstede-insights.com/ country-comparison/egypt/ (accessed 18 January 2020).

Cowell, F. (1990), Cheating the Government, The MIT press, Cambridge, MA.

Cowell, F. (1992), "Tax evasion and inequity”, Journal of Economic Psychology, Vol. 13, pp. 521-543.

Cowell, F. and Gordon, J. (1988), "Unwillingness to pay: tax evasion and public good provision", Journal of Public Economics, Vol. 36 No. 2, pp. 305-321.

Cummings, R., Martinez-Vazquez, J., McKee, M. and Torgler, B. (2006), "Effects of tax morale on tax compliance: experimental and survey evidence”, UC Berkeley, Berkeley Program in Law and Economics, available at: https:/escholarship.org/uc/item/8sh2w9fp. 
Czap, H.J., Czap, N.V. and Bonakdarian, E. (2010), "Walk the talk? The effect of voting and excludability in public goods experiments", Economics Research International, Vol. 2010, 768546, p. 15.

Dal Bó, P., Foster, A. and Putterman, L. (2010), "Institutions and behavior: experimental evidence on the effects of democracy", American Economic Review, Vol. 100 No. 5, pp. 2205-2229.

Deacon, R. (2009), "Public good provision under dictatorship and democracy", Public Choice, Vol. 139 Nos 1-2, pp. 241-262.

Di Nola, A., Kocharkov, G., Scholl, A. and Tkhir, A.M. (2021), "The aggregate consequences of tax evasion”, Review of Economic Dynamics, Vol. 40, pp. 198-227.

Djawadi, B. and Fahr, R. (2013), "The impact of tax knowledge and budget spending influence on tax compliance”, IZA Discussion Papers 7255, Institute of Labor Economics (IZA).

Fjeldstad, O.-H. (1996), "Tax evasion and corruption in local governments in Tanzania: Alternative economic approaches", Chr. Michelsen Institute Working Paper, WP 1996: 14.

Fujita, K. and Trope, Y. (2014), "Structured versus unstructured regulation: on procedural mindsets and the mechanisms of priming effects", Social Cognition, Vol. 32, Supplement, pp. 68-87.

Gale, W.G. and Krupkin, A. (2019), "How big is the problem of tax evasion?", available at: https:// www.brookings.edu/blog/up-front/2019/04/09/how-big-is-the-problem-of-tax-evasion/ (accessed 18 January 2020).

Hassan, I.e., Naeem, A. and Gulzar, S. (2021), "Voluntary tax compliance behavior of individual taxpayers in Pakistan", Financial Innovation, Vol. 7 No. 1, doi: 10.1186/s40854-021-00234-4.

Kahneman, D. and Tversky, A. (1972), "Subjective probability: a judgment of representativeness", Cognitive Psychology, Vol. 3 No. 3, pp. 430-454.

Kamei, K. (2016), "Democracy and resilient pro-social behavioral change: an experimental study", Social Choice and Welfare, Vol. 47 No. 2, pp. 359-378.

Kosters, M. and Van der Heijden, J. (2015), "From mechanism to virtue: evaluating Nudge theory", Evaluation, Vol. 21 No. 3, pp. 276-291.

KPMG (2020), "Tax newsletter issue no.7”, available at: https://assets.kpmg/content/dam/kpmg/us/ pdf/2020/07/tnf-egypt-july27-2020.pdf (accessed 17 July 2021).

Lamberton, C.P. and De Neve, J.-E. and Norton, M.I. (2014), "Eliciting taxpayer preferences increases tax compliance", doi: 10.2139/ssrn.2365751, available at SSRN: https://ssrn.com/ abstract $=2365751$.

Mansour, S., Wallace, S., Sadiraj, V. and Hassan, M. (2021), "How do electoral and voice accountability affect corruption? Experimental evidence from Egypt", European Journal of Political Economy, June, Vol. 68, 101994.

McEwen, C. and Maiman, R. (1986), "In search of legitimacy: toward an empirical analysis", Law and Policy, Vol. 8 No. 3, pp. 257-273.

Ng, I. and Tseng, L. (2008), "Evolution of homo economicus", American Journal of Economics and Sociology, Vol. 67, pp. 265-286.

Norris, E., Gradstein, M., Miryugin, F. and Misch, F. (2019), "Productivity and tax evasion", IMF Working Paper, (19/260).

OECD (2017), Behavioural Insights and Public Policy: Lessons from Around the World, OECD Publishing, Paris, doi: 10.1787/9789264270480-en.

Olken, B.A. (2010), "Direct democracy and local public goods: evidence from a field experiment in Indonesia", American Political Science Review, Vol. 104 No. 2, pp. 243-267.

Persson, T. and Tabellini, G.E. (2005), The Economic Effects of Constitutions, MIT Press, Massachusetts Institute of Technology.

Pommerehne, W. and Weck-Hannemann, H. (1996), "Tax rates, tax administration and income tax evasion in Switzerland", Public Choice, Vol. 88 No. 1, pp. 161-170. 
REPS

7,2

102
Rogers, T., Milkman, K.L. and Volpp, K.G. (2014), "Commitment devices: using initiatives to change behavior", Journal of the American Medical Association, Vol. 311 No. 20, pp. 2065-2066.

Russo, F.F. (2010), "Tax evasion and community effects in Italy", CSEF Centre for Studies in Economics and Finance Working Paper, University of Naples, p. 254.

Saidu, S. and Dauda, U. (2014), "Tax evasion and governance challenges in the Nigerian informal sector", Journal of Finance and Economics, Vol. 2 No. 5, pp. 156-161, doi: 10.12691/jfe-2-5-4.

Sandmo, A. (2005), "The theory of tax evasion: a retrospective view", National Tax Journal, Vol. 58 No. 4, pp. 643-663.

Schäfer, T. and Schwarz, M.A. (2019), "The meaningfulness of effect sizes in psychological research: differences between sub-disciplines and the impact of potential biases", Frontiers in Psychology, Vol. 10, p. 813, doi: 10.3389/fpsyg.2019.00813.

Simon, H.A. (1955), "A behavioral model of rational choice", The Quarterly Journal of Economics, Vol. 69 No. 1, pp. 99-118.

Steger, M., Kashdan, T. and Oishi, S. (2008), "Being good by doing good: daily eudaimonic activity and well-being”, Journal of Research in Personality, Vol. 42 No. 1, pp. 22-42.

Sussman, A.B. and Olivola, C.Y. (2011), "Axe the tax: taxes are disliked more than equivalent costs", Journal of Marketing Research, Vol. 48, Special Issue, pp. S91-S101.

Thaler, R.H. (1999), "Mental accounting matters", Journal of Behavioral Decision Making, Vol. 12 No. 3, pp. 183-206.

Thaler, R.H. and Benartzi, S. (2004), "Save more tomorrow: using behavioral economics to increase employee saving", Journal of Political Economy, Vol. 112 No. S1, pp. S164-S187.

Thaler, R.H. and Sunstein, C.R. (2008), Nudge: Improving Decisions About Health, Wealth, and Happiness, Yale University Press.

Torgler, B. (2005), “Tax morale and direct democracy”, European Journal of Political Economy, Vol. 21 No. 2, pp. 525-531.

Tversky, A. and Kahneman, D. (1973), "Availability: a heuristic for judging frequency and probability”, Cognitive Psychology, Vol. 5 No. 2, pp. 207-232.

Tversky, A. and Kahneman, D. (1974), "Judgment under uncertainty: heuristics and biases”, Science, Vol. 185 No. 4157, pp. 1124-1131.

Wenzel, M. (2005), "Misperceptions of social norms about tax compliance: from theory to intervention", Journal of Economic Psychology, Vol. 26, pp. 862-883.

White House (2011), "Your 2012 federal taxpayer receipt".

\section{Further reading}

Arab, N.G.O. (2014), Taxation Systems in Egypt and Tunisia, Arab NGO Network for Development, Beirut.

Bentham, J. and Lafleur, L.J. (1948), An Introduction to the Principles of Morals and Legislation, Hafner Publishing, New York, NY.

Chigbu, E.E. and Eze, L. (2012), "An empirical study on the causality between economic growth and taxation in Nigeria", Current Research Journal of Economic Theory, Vol. 4 No. 2, pp. 29-38.

Egypt Government Budget (2018), available at: https://tradingeconomics.com/egypt/governmentbudget (accessed 18 January 2020).

Enterprise (2019), "Gov't looking to reduce Egypt's budget deficit to 5\% within two years -Maait", available at: https:/enterprise.press/stories/2019/09/24/govt-looking-to-reduce-egypts-budgetdeficit-to-5-within-two-years-maait/ (accessed 18 January 2020).

Head of Tax Authority: Tax evasion rate in Egypt is not less than 40\% (2019), available at: https:// www.elwatannews.com/news/details/4453726 (accessed 18 January 2020). 
Hirschi, T. and Stark, R. (1969), "Hellfire and delinquency", Social Problems, Vol. 17, pp. 202-213.

HM Revenue \& Customs (2019), "Measuring Tax Gaps 2019 Edition Tax Gap Estimates for 2017-18”, Crown, pp. 6-23, available at: https://assets.publishing.service.gov.uk/government/uploads/ system/uploads/attachment_data/file/820979/Measuring_tax_gaps_2019_edition.pdf (accessed 29 December 2019).

Jalili, A.R. (2012), "The ethics of tax evasion: an Islamic perspective", in The Ethics of Tax Evasion, Springer, New York, NY, pp. 167-199.

Mill, J.S. and Ashley, W.J. (1965), Principles of Political Economy: With Some of Their Applications to Social Philosophy, A.M. Kelley, bookseller, New York.

Ministry of Finance (2018), Publication of Preparation of Public Budget for the Fiscal Year 2019/2020, Ministry of Finance, Cairo.

OECD (2010), "Business climate development strategy", Tax Policy Assessment.

Siddiqi, M.W. and Ilyas, M. (2011), "Impact of revenue gap on budget deficit, debt burden and economic growth: an evidence from Pakistan", International Journal of Human and Social Sciences, Vol. 6 No. 2, pp. 89-98.

Tax revenues represent $72 \%$ to $\% 75$ of state's treasury (2019), available at: https://www.egypttoday. com/Article/3/63811/Tax-revenues-represent-72-to-75-of-state-s-treasury (accessed 18 January 2020).

Thaler, R.H. (2018), "From cashews to nudges: the evolution of behavioral economics", American Economic Review, Vol. 108 No. 6, pp. 1265-1287.

The World Factbook - Central Intelligence Agency (2019), available at: https:/www.cia.gov/library/ publications/the-world-factbook/ (accessed 3 January 2020).
How can tax

compliance be incentivized? 
REPS

7,2

\begin{tabular}{|c|c|c|c|c|}
\hline \multirow[b]{2}{*}{104} & Variable & Type & Proxies & Measurement \\
\hline & $\begin{array}{l}\text { Tax } \\
\text { compliance }\end{array}$ & $\begin{array}{l}\text { Dependent } \\
\text { variable }\end{array}$ & Willingness to comply & \multirow{2}{*}{$\begin{array}{l}\text { Dummy variable that takes } \\
0 \text { : Paid the wrong value } \\
\text { 1: Reported the problem } \\
\text { Dummy variable that takes } \\
0 \text { : Control } \\
\text { 1: Treatment }\end{array}$} \\
\hline & Voice & $\begin{array}{l}\text { Independent } \\
\text { variable }\end{array}$ & $\begin{array}{l}\text { Voice in the decision-making } \\
\text { process }\end{array}$ & \\
\hline & Empathy & $\begin{array}{l}\text { Independent } \\
\text { variable }\end{array}$ & $\begin{array}{l}\text { Empathy-triggering } \\
\text { information }\end{array}$ & $\begin{array}{l}\text { Dummy variable that takes } \\
0 \text { : Control } \\
\text { 1: Treatment }\end{array}$ \\
\hline & Honesty & Control & $\begin{array}{l}\text { Index of average } 3 \text { honesty } \\
\text { questions }\end{array}$ & $\begin{array}{l}\text { Continuous variable that ranges from } \\
\text { zero to one } \\
0 \text { : Totally dishonest } \\
1 \text { : Totally honest }\end{array}$ \\
\hline & Emotional & Control & $\begin{array}{l}\text { Index of average } 3 \text { empathy } \\
\text { questions }\end{array}$ & $\begin{array}{l}\text { Continuous variable that ranges from } \\
\text { zero to one } \\
0 \text { : Totally apathetic } \\
\text { 1: Totally empathetic }\end{array}$ \\
\hline & Religiosity & Control & $\begin{array}{l}\text { Index of average } 3 \text { religiosity } \\
\text { questions }\end{array}$ & $\begin{array}{l}\text { zero to one } \\
0 \text { : Non-religious } \\
1 \text { : Religious }\end{array}$ \\
\hline & Age & Control & Age & $\begin{array}{l}\text { Categorical variable that ranges from } \\
1 \text { till } 4 \\
1 \text { : Age bracket } 15-24 \\
4 \text { : Age bracket } 45+\end{array}$ \\
\hline & Female & Control & Female & $\begin{array}{l}\text { Dummy variable that takes } \\
\text { 0: Male } \\
\text { 1: Female }\end{array}$ \\
\hline & Education & Control & Level of current education & $\begin{array}{l}\text { Categorical variable that ranges from } \\
1 \text { till } 3 \\
\text { 1: High school } \\
\text { 3: Master's degree }\end{array}$ \\
\hline & Income & Control & Level of monthly income & $\begin{array}{l}\text { Categorical variable that ranges from } \\
1 \text { till } 6 \\
1 \text { : Less than } 10,000 \\
6: \text { More than } 30,000\end{array}$ \\
\hline $\begin{array}{l}\text { Table A1. } \\
\text { Definition of variables } \\
\text { and their measurement }\end{array}$ & Fees & Control & Level of annual tuition fees & $\begin{array}{l}\text { Categorical variable that ranges from } \\
1 \text { till } 6 \\
1 \text { : Less than } 2,000 \\
6 \text { : More than } 15,000\end{array}$ \\
\hline
\end{tabular}

Appendix 1

Variables and their measurement 


\section{Control Group [21]}

Before you start, please read the following note

The information being collected in this study is part of a research project and will only be used for research purposes. Your participation in this study will remain completely anonymous to the researcher and other participants. So, please be as honest and truthful as you can.

(1) Age

- $15-24$

- $25-34$

- $35-44$

- $45+$

(2) Gender

- Male

- Female

(3) Which education level are you currently enrolled in?

- High School

- Bachelor's Degree

- Master's Degree

- Other; please specify

(4) Do you agree or disagree with the following statements? (Strongly Disagree - Strongly Agree)

- In today's society, one has to lie or cheat at least occasionally in order to succeed.

- I do not mind lying on my resume if it gets me the job I want.

- I am more ethical than most people I know.

(5) For the following statements, please indicate how well each describes you: (A lot $-\mathrm{A}$ little - Not that much - Not at all)

- I often have tender, concerned feelings for people who are less fortunate than me.

- "Sometimes it's better to be more emotional than rational."

- When I am reading an interesting novel or watching an interesting movie, I imagine how I would feel if the events in the story were happening to me.

(6) Would you describe yourself as ...?

- Very religious

- A little religious

- Moderately religious

- Neither religious nor non-religious

- A little non-religious

- Very non-religious 
REPS

7,2

106
(7) For the following statements, please indicate how frequently you ... (Daily - From 2 to 3 times a week - Once a week - Once a month - Less than that)

- Read your holy scripture, such as the Quran or the Bible, not counting any reading that happens during prayers.

- Voluntarily watch religious TV shows, religious talks, religious videos, or read religious articles and social media posts ... etc.

(8) Which of these categories best describes the monthly combined income of your family? (In Egyptian Pounds)

- Less than 10,000

- $10,000-14,999$

- $15,000-19,999$

- $20,000-24,999$

- $25,000-30,000$

- More than 30,000

(9) What is the level of your annual college tuition fees? (In Egyptian Pounds)

- Less than 2,000

- $2,000-4,999$

- $5,000-7,999$

- $8,000-10,999$

- $11,000-15,000$

- More than 15,000

(10) Your college decided to increase the annual tuition fees by $5 \%$. The following day, you went to pay your tuition fees. After checking the system/student services to see the amount you have to pay, you realized that the extra $5 \%$ were not added to your fees. You are the only one aware of this problem. What will you do?

- Report the problem and decide to pay the extra $5 \%$

- Only pay the amount you see on the system

Thank you for your participation.

\section{Voice Treatment}

Question 10: Imagine you are the Head of the Student Union. Your college always consults you on how to spend any increase in the tuition fees, and you have a major say on this.

Now, your college decided to increase the annual tuition fees by $5 \%$. The following day, you went to pay your tuition fees. After checking the system/student services to see the amount you have to pay, you realized that the extra $5 \%$ were not added to your fees. You are the only one aware of this problem. What will you do?

- Report the problem and decide to pay the extra 5\%

- Only pay the amount you see on the system

\section{Empathy Treatment}

Question 10: Around 18,090 students of Cairo University are under the poverty line. (This piece of information was gathered from the Office of Cairo University President). These students do not have 
adequate incomes to pay their annual tuition fees and fully rely on the financial aid provided by their colleges. This financial aid is gathered from increases in the tuition fees of all the colleges at Cairo University.

Now, your college decided to increase the annual tuition fees by $5 \%$. The following day, you went to pay your tuition fees. After checking the system/student services to see the amount you have to pay, you realized that the extra $5 \%$ were not added to your fees. You are the only one aware of this problem. What will you do?

- Report the problem and decide to pay the extra $5 \%$

- Only pay the amount you see on the system

\section{Corresponding author}

Sarah Mansour can be contacted at: SARAH.MANSOUR@feps.edu.eg

For instructions on how to order reprints of this article, please visit our website: 